\title{
Feasibility Study on Windrow Co-composting to Recycle Industrial Eggshell Waste
}

\author{
Margarida J. Quina • Micaela A. R. Soares • \\ Andreia A. Ribeiro - Ana P. Marques • \\ Isabel H. Costa $\cdot$ Maria C. Magalhães
}

Received: 31 October 2012/ Accepted: 7 February 2013/Published online: 16 February 2013

(C) Springer Science+Business Media Dordrecht 2013

\begin{abstract}
The main objective of this study was to evaluate the feasibility of recycling large quantities of industrial eggshell waste through turned windrows composting in order to obtain a value-added soil improver. For that, four different formulations were tested to produce stable composts with adequate properties to be further used for agronomic applications such as amendment in soils with acid characteristics and/or with low calcium concentration. The eggshell waste is mainly an inorganic animal by-product, and thus its co-composting was conducted with farm wastes (horse and chicken manures) and grass clipping. The windrows were aerated periodically and monitored during 50 days regarding temperature, moisture, $\mathrm{pH}$, conductivity, and carbon/nitrogen ratio $(\mathrm{C} / \mathrm{N})$. The thermophilic phase lasted for 10-20 days. At the end, moisture, $\mathrm{pH}$, electrical conductivity, organic matter, $\mathrm{C} / \mathrm{N}$ ratio, and toxic heavy metals $(\mathrm{Cd}, \mathrm{Cr}, \mathrm{Pb}, \mathrm{Cu}, \mathrm{Ni}, \mathrm{Zn})$ were determined. The microbiological assessment involved total mesophilic heterotrophic bacteria, total coliform bacteria, thermotolerant coliform bacteria, E.coli and spores of sulphite-reducing clostridia. The assessment of maturity based on germination index and stability by using Dewar selfheating test and respirometry showed that all the composts were mature and stable, with adequate properties for
\end{abstract}

M. J. Quina ( $₫)$ · M. A. R. Soares · A. A. Ribeiro ·

A. P. Marques

CIEPQPF-Research Centre on Chemical Processes

Engineering and Forest Products, Department of Chemical

Engineering, University of Coimbra, Rua Sílvio Lima,

3030-790 Coimbra, Portugal

e-mail: guida@eq.uc.pt

M. A. R. Soares · I. H. Costa · M. C. Magalhães

Cernas-Natural Resources, Environment and Society Research Centre, Coimbra College of Agriculture of Polytechnic Institute of Coimbra, Bencanta, 3040-316 Coimbra, Portugal agronomic applications. This study evidenced that large quantities (up to $30 \%$ in weight) of eggshell waste may be converted into calcium-rich marketable compost by thermophilic windrows composting.

Keywords Eggshell waste - Animal by-product . Composting $\cdot$ Windrow composting system

\section{Introduction}

The industry of pasteurised liquid eggs and boiled eggs produces large amounts of eggshell (ES) waste which is classified in European Regulations as an animal by-product (ABP) not intended to human consumption. A report of the European Commission published in 2004 estimated the amount of eggshell waste produced in Europe in 30 million kg per year [1]. However, adequate management strategies are not yet well established for this waste, most of which is now landfilled. The options for recycling eggshell waste are limited and mainly related with animal food preparation or adsorbent materials for dyes or heavy metals removal, at laboratorial scale [2-4]. Therefore, landfill disposal has traditionally been used [4,5], although current EU policies recommend it only as a last option, encouraging recycling and waste recovery. Animal manure, classified also as ABP, is perhaps the oldest and most successful fertilizer used by man as soil conditioner. However land application of raw manure is often the main cause of water contamination by pathogenic bacteria [6].

According to the legislation in force, Regulation (EC) No. 1069/2009 of the European Parliament and the Council, animal by-products are categorized into three categories which reflect the level of risk to public and animal health arising from those wastes. For each category, a list of disposal and use alternatives is imposed in that Regulation. ES 
and manure are included in the inventory of Category 3 and Category 2, respectively. For both materials, one of the alternatives for disposal/use is composting prior to soil incorporation, in order to reduce spreading risk of pathogens to the environment and human health.

In recent years, several factors have contributed to a renewed attention to composting process. EU Landfill Directive (Council Directive 99/31/EC of 26 April 1999) has established that by 2016 the Member States must reduce biodegradable waste going to landfill by $65 \%$ measured against a 1995 baseline. Recently also the Waste Framework Directive (Directive 2008/98/EC) reinforces the waste management hierarchy in five-steps: prevention is the best alternative, followed by re-use, recycling and other forms of recovery (e.g. incineration with energy recovery), and disposed of in landfills as last option. In this scope, composting has been identified as an environmentally sound alternative to landfill disposal, once it converts by different microbial communities in aerobic conditions, organic wastes into a humus-like product to be used as biofertilizer or soil amendment material [7]. On the other hand, composting is often promoted as a means of sanitizing manure in order to avoid pathogenic bacteria spreading into the environment [6]. Composting has been used to recycle wastes such as municipal solid wastes [8,9], sewage sludges [10], olive-mill by-products [11] and many others. It is important to note that according to EU data, compost made from municipal waste increase from $13 \times 10^{6}$ in 1995 to $43.5 \times 10^{6}$ in 2008 , accounting for $17 \%$ of the waste produced by the Member States of EU.

Although eggshell waste is poor in organic matter (about $94 \%(\mathrm{w} / \mathrm{w})$ is $\mathrm{CaCO}_{3}$ [12]) its co-composting with proper organic materials might represent an effective method for recycling this waste, eliminating the risk to the environment and human health, as a source of transmission of pathogens. In addition, the finished compost may overcome physical, chemical and structural soil problems by incorporating a compost rich in organic matter, nutrients including calcium, and alkalizing agents. To the best of our knowledge, eggshell waste composting with other ABP has not been considered. The only study found in the literature has used microbial inoculants to aid in the humus buildup [13].

Thus, the main objective of this study was to analyse the possibility of recycling high amounts of industrial eggshell waste and animal manure through indoor windrow composting, using the microbial community naturally occurring in wastes.

\section{Materials and Methods}

Feedstocks and Windrow Composting

Eggshell waste (ES) was supplied by a Portuguese company that produces pasteurised liquid chicken eggs and boiled eggs. This inorganic waste was mixed with horse manure (HM) that includes bedding straw, chicken manure (CM) without any bedding and grass clipping (GC). Four indoor windrows (pile 1-4) were prepared as detailed in Table 1, that correspond to triangular shaped heaps (with nearly $2 \mathrm{~m}$ width and $1.5 \mathrm{~m}$ height).

The initial mixtures were well homogenized and windrows were turned at day 9,28 and 36 by mechanical turning to improve oxygen concentration and to uniform moisture and heat. Moisture content was adjusted periodically and temperature was monitored over time, at approximately $56 \mathrm{~cm}$ deep, using a meter long dial temperature probe (Delta $\mathrm{Ohm}$ ), at eight different points for pile 1 and at five points for pile $2-4$.

\section{Sampling}

Six composite samples were collected at day 1, 7, 14, 21, 29 and 50 , by taking ten sub-samples at different points of each pile, regularly distributed along the length. The subsamples were taken at nearly $20 \mathrm{~cm}$ from the external surface and then mixed, sliced into four parts, one being rejected. This procedure was repeated in order to obtain samples of $2-3 \mathrm{~kg}$ for further analysis.

\section{Physical and Chemical Properties}

The moisture content was determined by drying samples at $105^{\circ} \mathrm{C}$ for $24 \mathrm{~h}$ [14]. $\mathrm{pH}$ and electrical conductivity were measured in suspensions of compost in deionised water (volume-to-mass ratio of 10:1).

Heavy metals $(\mathrm{Cd}, \mathrm{Cr}, \mathrm{Cu}, \mathrm{Ni}, \mathrm{Pb}, \mathrm{Zn})$ and macronutrients $(\mathrm{Ca}, \mathrm{Mg}, \mathrm{Na}, \mathrm{K})$ were quantified by flame atomic absorption spectrometry (Perkin Elmer-3000) after aqua regia extraction according to European standard EN 13650:2001. The total phosphorus content was measured by vanadate-molybdate spectrophotometric method, after sample incineration at $550{ }^{\circ} \mathrm{C}$ and ash solubilisation in hydrochloric acid (1:1).

Nitrogen content was evaluated according to European standard EN 13654-1:2001 (Kjeldahl nitrogen). Carbon

Table 1 Compositions tested in windrow composting system (pile 1-4)

\begin{tabular}{lclllll}
\hline & $V\left(\mathrm{~m}^{3}\right)$ & $\mathrm{SA}: V\left(\mathrm{~m}^{2} \mathrm{~m}^{-3}\right)$ & \multicolumn{4}{c}{ Composition $(\% \mathrm{w} / \mathrm{w})$} \\
\cline { 5 - 7 } & & & HM & CM & GC & ES \\
\hline Pile 1 & 11.0 & 3.9 & 31 & 37 & 12 & 20 \\
Pile 2 & 7.0 & 2.7 & 33 & 38 & 9 & 20 \\
Pile 3 & 7.0 & 2.7 & 33 & 28 & 9 & 30 \\
Pile 4 & 7.5 & 2.8 & 16 & 31 & 20 & 33
\end{tabular}

$S A: V$ superficial area to volume ratio, $H M$ horse manure, $C M$ chicken manure, $G C$ grass clipping, $E S$ eggshell waste 
content was determined with a Carbon-Sulphur Analyzer (Leco Instruments, model SC-144 DR), where the carbon present in the compost was oxidized to carbon dioxide by heating at $550{ }^{\circ} \mathrm{C}$. To calculate the organic matter, a factor of 1.72 was used to the carbon content value [14].

\section{Microbiological Analysis}

For microbiological analysis a suspension was prepared by adding $10 \mathrm{~g}$ (wet weight) of sample to $90 \mathrm{~mL}$ of sterile Ringer solution (1/4), and ten-fold serial dilutions were then made, also in sterile Ringer solution (1/4). The microbiological parameters analyzed, culture methods used, culture media and incubation conditions are summarized in Table 2.

\section{Phytotoxicity Tests}

To determine whether composts had substances that inhibited seed germination or radicle growth, some phytotoxicity bioassays were performed and the germination index (GI) was calculated. Initially, a set of tests using finished compost from pile 1 (referred as $\mathrm{C} 1$ ) were conducted to assess the most sensitive seed among garden cress, lettuce and tomato seeds. Then, all finished composts $(\mathrm{C} 1-\mathrm{C} 4)$ from piles 1 to 4 were evaluated in terms of phytotoxicity.

For evaluating GI, water extracts were obtained from composts according to [15]. Then, ten seeds were evenly distributed over filter paper in Petri dishes (10-cm diameter) and moistened with $4 \mathrm{~mL}$ of the extract. Three replicates per sample were incubated at $27^{\circ} \mathrm{C}$ in dark conditions for $48 \mathrm{~h}$. After this period, the number of germinated seeds and their root length were measured, and GI was determined by Eq. (1), as a percentage of a control (with deionised water):

$G I=\frac{R S G \cdot R R G}{100}$

where RSG is the relative seed germination and RRG the relative root growth defined by Eqs. (2) and (3).
$R S G=\frac{N_{S G}}{N_{S G C}} .100$

$R R G=\frac{L_{R G}}{L_{R C}} .100$

where $\mathrm{N}_{\mathrm{SG}}$ is the number of seeds germinated in each extract, $\mathrm{N}_{\mathrm{SGC}}$ the number of seeds germinated in control, $\mathrm{L}_{\mathrm{RG}}$ the root length of seeds germinated in each extract and $\mathrm{L}_{\mathrm{RC}}$ the root length of seeds germinated in control.

\section{Stability Evaluation}

The biological stability degree of finished composts produced $(\mathrm{C} 1-\mathrm{C} 4)$ was determined by self heating test and respirometric essays. The self-heating tests were carried out using Dewar flasks, where $1.5 \mathrm{dm}^{3}$ of wet compost sample was introduced and temperature monitored for 10 day. The stability degree of compost was established according to the difference between the maximum temperature recorded and the ambient temperature outside the flask. Major differences in temperature correspond to composts less stable.

An experimental apparatus consisting in an oxygen probe (WTW inilab Oxi 740 with StirrOx) coupled to a sample bottle provided with a stirring system was used for respirometric essays. Temperature was kept at $30{ }^{\circ} \mathrm{C}$, using a water bath where the sample bottle was immersed. To compensate the depletion of the oxygen consumed by the microorganisms, a small fish-tank air pump was used. Sample preparation procedure followed the methodology proposed by Lasaridi and Stentiford [16]. In particular, the maximum specific oxygen uptake rate, SOUR ( $\mathrm{mg} \mathrm{O}_{2} \mathrm{~g}^{-1} \mathrm{VS} \mathrm{h}^{-1}$ ) was calculated according to Eq. (4).

SOUR $=\frac{60 \cdot|S|_{\max } V}{m \cdot D S \cdot V S}$

where 60 is a conversion factor from minutes to hours, $|S|_{\max }$ the absolute maximum slope $\left(\mathrm{mg} \mathrm{O}_{2} \mathrm{~L}^{-1} \mathrm{~min}^{-1}\right)$,

Table 2 Microbiological parameters analyzed, culture methods and media used, incubation conditions and unit expression of the microbiological analysis

\begin{tabular}{|c|c|c|c|c|}
\hline Parameter & $\begin{array}{l}\text { Culture } \\
\text { method }\end{array}$ & Culture media & Incubation & Units \\
\hline $\begin{array}{l}\text { Total mesophilic } \\
\text { aerobic bacteria }(\mathrm{MB})\end{array}$ & Pour plate & Plate count agar & $\begin{array}{l}30 \pm 1{ }^{\circ} \mathrm{C} \\
72 \pm 3 \mathrm{~h}\end{array}$ & $\mathrm{CFU} \mathrm{g} \mathrm{g}^{-1}$ \\
\hline $\begin{array}{l}\text { Total coliform } \\
\text { bacteria }(\mathrm{CB})\end{array}$ & Multiple tubes & Brilliant green bile $2 \%$ broth & $\begin{array}{l}30 \pm 1{ }^{\circ} \mathrm{C} \\
24+24 \mathrm{~h}\end{array}$ & MPN $\mathrm{g}^{-1}$ \\
\hline $\begin{array}{l}\text { Thermotolerant coliform } \\
\text { bacteria (TCB) and } E \text {. coli }\end{array}$ & Multiple tubes & $\begin{array}{l}\text { Brilliant green bile } 2 \% \text { broth } \\
\text { and peptone broth }\end{array}$ & $\begin{aligned} 44.5 & \pm 0.5^{\circ} \mathrm{C} \\
24 & +24 \mathrm{~h}\end{aligned}$ & MPN g ${ }^{-1}$ \\
\hline $\begin{array}{l}\text { Spores of sulphite-reducing } \\
\text { clostridia (SSRC) }\end{array}$ & Multiple tubes & $\begin{array}{l}\text { Reinforced clostridium medium } \\
\quad+\text { agar-agar (plus sodium sulphite } \\
\text { and ammonium iron sulphate) }\end{array}$ & $\begin{array}{l}37 \pm 1^{\circ} \mathrm{C} \\
1-5 \text { days }\end{array}$ & $\mathrm{MPN} \mathrm{g}^{-1}$ \\
\hline
\end{tabular}

$C F U$ colony forming units, $M P N$ most probable number 
$V$ the volume of the suspension (L), $m$ the mass of the compost sample ( $\mathrm{g}$, wet weight), DS the fraction of dry solids (from 0 to 1.0), and VS the fraction of volatile solids (from 0 to 1.0).

\section{Statistical Analysis}

ANOVA and Tukey test were used to compare the mean values of the response variables observed in each treatment. The differences between any pair of treatment means were tested using the least significant difference test with a $p$ value (significance level) of $5 \%$. Statistical analyses were performed using Matlab (Version 7.8.0.347, Mathworks, USA).

\section{Results and Discussion}

\section{Characterisation of the Composting Mixtures}

The physical and chemical properties of the initial mixtures tested in piles 1-4 are listed in Table 3. In general, it is well recognized that the main parameters to be set at the beginning of the composting process are moisture and $\mathrm{C} / \mathrm{N}$ ratio and their optimal ranges are 50-60\% and 25-30:1, respectively [17-19]. In this study, at the start of the composting process, moisture content ranged between 43 and $49 \%$. With respect to $\mathrm{C} / \mathrm{N}$ ratio, low values were found in all initial mixtures (15.2-17.8), but this aspect seemed not to limit the process evolution (results discussed in "Monitoring of Composting Processes" section). In fact, Huang et al. [17] studied the effect of low $\mathrm{C} / \mathrm{N}$ ratio $(\mathrm{C} / \mathrm{N}=15)$ in composting of pig manure with sawdust and concluded that longer composting periods were needed to attain compost stabilization, but the temperature profile reached $60{ }^{\circ} \mathrm{C}$ and thermophilic phase lasted for 32 days, which is long enough for suppression of pathogens. Bustamante et al. [20] also studied the co-composting of distillery wastes with animal manures (cattle and poultry) starting from mixtures with $\mathrm{C} / \mathrm{N}$ ratios of 20.2 and 13.1. In the case of mixtures with $\mathrm{C} / \mathrm{N}$ of 13.1 , the maximum temperature did not exceed $50{ }^{\circ} \mathrm{C}$, but the authors concluded that good degree of maturity was reached in the finished compost.

High levels of calcium were found in all mixtures tested, as a result of the significant quantities of eggshell waste used. Other major elements required for microbiological growth, such as $\mathrm{P}, \mathrm{K}, \mathrm{Na}$, and $\mathrm{Mg}$, were present in enough concentrations in the starting materials. The toxic heavy metals $(\mathrm{Cd}, \mathrm{Cr}, \mathrm{Pb}, \mathrm{Cu}, \mathrm{Ni}$ and $\mathrm{Zn})$, as expected, were detected in low concentrations.
Table 3 Physical and chemical properties of the composting mixtures

\begin{tabular}{lrrrr}
\hline Parameter & Pile1 & Pile 2 & Pile 3 & Pile 4 \\
\hline Moisture (\% w/w) & 43.0 & 42.0 & 48.0 & 49.0 \\
$\mathrm{pH}$ & 7.8 & 7.7 & 7.5 & 7.5 \\
$\mathrm{EC}\left(\mathrm{mS} \mathrm{cm}^{-1}\right)$ & 1.3 & 1.3 & 1.3 & 1.2 \\
$\mathrm{C} / \mathrm{N}$ & 17.8 & 17.8 & 16.6 & 15.2 \\
$\mathrm{Ca}(\%)$ & 7.2 & 7.5 & 8.8 & 8.8 \\
$\mathrm{P}(\%)$ & 0.20 & 0.18 & 0.17 & 0.19 \\
$\mathrm{~K}(\%)$ & 0.45 & 0.46 & 0.38 & 0.36 \\
$\mathrm{Na}(\%)$ & 0.10 & 0.12 & 0.11 & 0.10 \\
$\mathrm{Mg}(\%)$ & 0.27 & 0.26 & 0.28 & 0.28 \\
$\mathrm{Cd}\left(\mathrm{mg} \mathrm{kg}^{-1}\right)$ & $<0.25$ & $<0.25$ & $<0.25$ & $<0.25$ \\
$\mathrm{Cr}\left(\mathrm{mg} \mathrm{kg}^{-1}\right)$ & 45.2 & 53.4 & 35.7 & 34.8 \\
$\mathrm{~Pb}\left(\mathrm{mg} \mathrm{kg}^{-1}\right)$ & 5.6 & 4.9 & 5.3 & 7.3 \\
$\mathrm{Cu}\left(\mathrm{mg} \mathrm{kg}^{-1}\right)$ & 10.9 & 12.3 & 10.3 & 12.5 \\
$\mathrm{Ni}\left(\mathrm{mg} \mathrm{kg}^{-1}\right)$ & 8.6 & 9.5 & 10.1 & 10.1 \\
$\mathrm{Zn}\left(\mathrm{mg} \mathrm{kg}^{-1}\right)$ & 50.2 & 48.7 & 34.1 & 42.0 \\
\hline
\end{tabular}

$E C$ electrical conductivity, $C / N$ carbon to nitrogen ratio

\section{Monitoring of Composting Processes}

In this study, four indoor windrows with different compositions (Table 1) were monitored for 50 days, with respect to temperature, moisture, $\mathrm{pH}$ and electrical conductivity. Figure 1a, b show the evolution of temperature, which corresponds to one of the most important parameters in composting process monitoring, since it determines the microorganisms dynamics, the biological reaction rate and also the quality of the finished composts. The vertical lines represent the range of temperature measured in the different points of each windrow and arrows indicate turning events.

The temperature profiles showed that the starting materials were already hot $\left(>30^{\circ} \mathrm{C}\right)$ when windrows were set up, because some ageing manures were used. In fact, the horse manure employed in this study was stored for two weeks in an atrium, and thus the microbial degradation of readily biodegradable matter was already started. According to $\mathrm{Li}$ et al. [21] composting of aged manures reaches lower peak temperature, takes longer time to achieve stability and induces higher ammonia emissions. Therefore, one might expect that the temperature profiles shown in Fig. 1 could display a more pronounced thermophilic phase, if fresh horse manure had been used. For pile 1 and 2 (with $20 \%$ ES) thermophilic phase lasted nearly 20 days and it took approximately 6 days to reach $50{ }^{\circ} \mathrm{C}$ which was the maximum average temperature registered, besides superior temperature values were found in some points of the windrows, specially in the core region of the piles (vertical lines in Fig. 1a). The maturation phase is well 
(a)

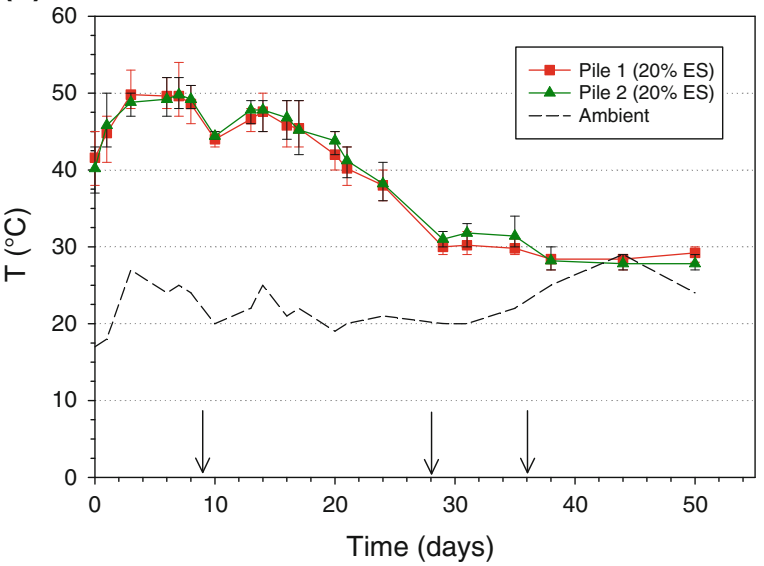

(b)

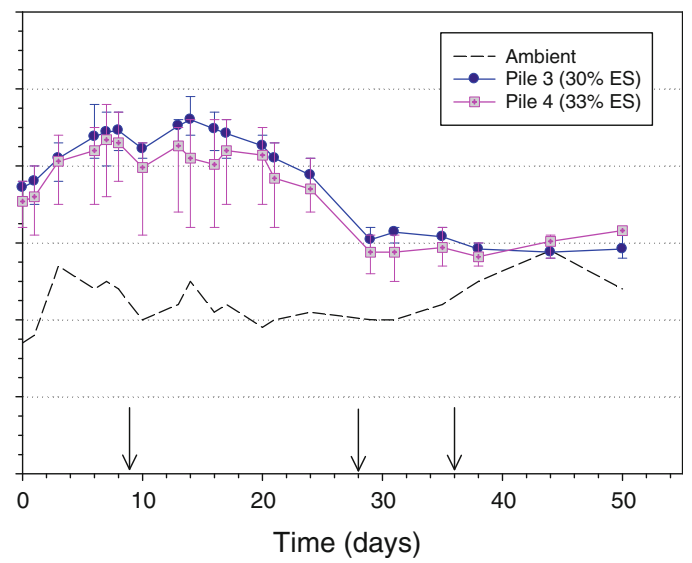

Fig. 1 Temperature profiles during the composting process (vertical lines represent the range of temperature measured in different points of windrows; arrows indicate mechanical turning). a piles with $20 \%$ of ES, b piles with $\sim 30 \%$ of eggshell (ES)

identified, since the temperature decreased to the ambient range and the composting turning or moisture correction did not lead to significant changes in this variable. Figure $1 \mathrm{~b}$ shows similar trends for temperature even when using nearly $30 \%$ ES. However, in these cases thermophilic phase started 6 days later than for windrows with $20 \%$ ES, and lasted 14 days. In addition, the maximum average temperature recorded was 45 and $43{ }^{\circ} \mathrm{C}$, for pile 3 and 4 , respectively; the maximum absolute values observed were 49 and $47{ }^{\circ} \mathrm{C}$, respectively.

During composting, all windrows revealed a significant tendency to lose water, and thus moisture adjustments were done to maintain its content close to $50 \%$ (data not shown). Figure 2 shows temporal evolution of the $\mathrm{pH}$, which was similar between the piles and followed a pattern indicated by other studies [22, 23].

Initially, $\mathrm{pH}$ increased to near 8.5 , but after 20 days it tended to decrease and stabilized in the range of 7.5-8.5. Electrical conductivity (EC) profiles were also included in Fig. 2, and revealed a slight increase over time. At the end, piles 1 and 2 exhibited higher values due to the high amount of manures used in these mixtures. The final EC is close to $1.5 \mathrm{mS} \mathrm{cm}{ }^{-1}$, which is not a critical value for soil amendment.

\section{Compost Properties}

\section{Physical and Chemical Characteristics}

The main physical and chemical characteristics determined on the finished composts $\mathrm{C} 1-\mathrm{C} 4$ (obtained from piles 1 to 4) are shown in Table 4, as well as the criteria for the award of the Community Ecolabel to soil improvers (Commission Decision 2006/799/EC). All composts turned to a dark brown colour, rich in humus like coarse material

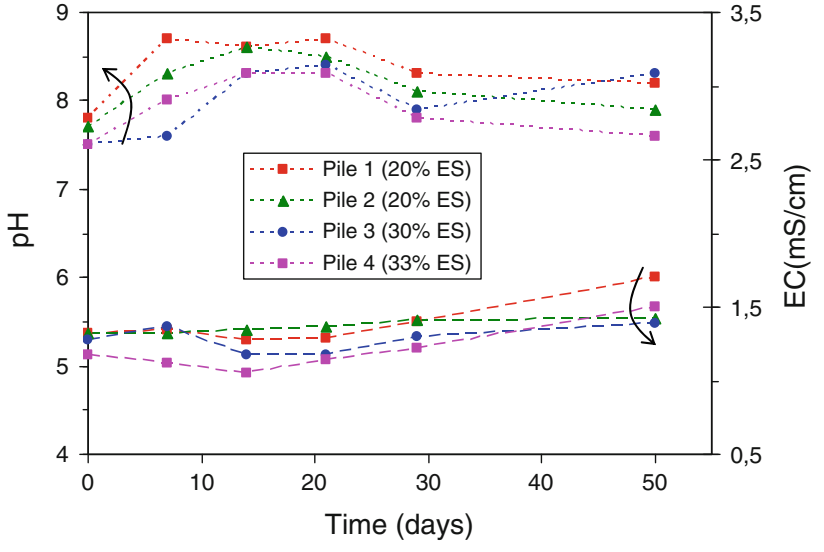

Fig. $2 \mathrm{pH}$ (small dashed lines) and electrical conductivity (long dashed lines) evolution during composting process

and free of foul odours. Small particles of eggshell were well visible in the finished composts, but in all the cases there is agreement with the criteria listed in Table 4. Indeed, electrical conductivities (EC) are close to the threshold of $1.5 \mathrm{mS} \mathrm{cm}^{-1}$, due to animal manures were used as organic substrate [24]. In addition, it is well known that the content of heavy metals in composts may be considered a critical parameter in terms of quality. By comparing the concentrations of $\mathrm{Cd}, \mathrm{Cr}, \mathrm{Pb}, \mathrm{Cu}, \mathrm{Ni} \mathrm{Zn}$ present in the composts with the criteria for obtaining $\mathrm{EU}$ Ecolabel, no critical values were found. It is important to note that the finished composts are Ca-rich materials and its amount is nearly twice higher than in the starting materials (Table 3). This fact is a consequence of both the overall mass reduction during the composting and the chemical stability of the calcium mineral in ES (mainly $\mathrm{CaCO}_{3}$ ). As aforementioned, these composts may have a positive effect when used to increase soil $\mathrm{pH}$ or to improve soils with low $\mathrm{Ca}$ content (considered a major element for plant growth). 


\section{Microbiological Assessment}

The total coliform bacteria (CB), thermotolerant coliform bacteria (TCB), E. coli and sulphite-reducing clostridia (SSRC) were determined in the finished composts and the results are indicated in Fig. 3a. Total mesophilic aerobic bacteria (MB) levels quantified in mixed starting raw materials and final composts are presented in Fig. 3b. In this regard, it is important to note that Salmonella has been reported as a major issue concerning the sanitisation of compost [25]. However, these microorganisms were not included in our microbiological assessment due to logistical problems in our laboratory at the time of the studies, but in the future this analysis should be included in the research.

Faecal bacteria were identified in all composts produced. The results showed that TCB and E. coli levels varied between 0.9 and $2.9 \log \mathrm{MNP} \mathrm{g}^{-1}$ and $0.9-2.7 \log$ MNP $\mathrm{g}^{-1}$, respectively. In matured compost, faecal bacteria are of particular interest from a hygienic point of view, because they can be used as bioindicators of the presence of potential pathogens and of the grade of sanitization of the compost. The levels of TCB and E. coli quantified in the matured composts are lower than the criteria defined by the Commission Decision 2006/799/CE $\left(<1,000 \mathrm{MPN} \mathrm{g}^{-1}\right)$ for agricultural use or for commercialisation of the compost.

Compost produced in pile 4 presented the higher levels of TCB and E. coli indicating that probably thermophilic phase was not long enough to permit pathogen inactivation. In fact, the temperature profile (Fig. 1) in this pile achieved

Table 4 Physical and chemical characterization of the finished composts $(\mathrm{C} 1-\mathrm{C} 4)$

\begin{tabular}{lccccl}
\hline Parameter & \multicolumn{2}{l}{ Compost } & $\begin{array}{l}\text { Decision } \\
\text { 2006/799/EC }\end{array}$ \\
\cline { 2 - 5 } & $\mathrm{C} 1$ & $\mathrm{C} 2$ & $\mathrm{C} 3$ & $\mathrm{C} 4$ & \\
\hline Moisture (\%) & 43.9 & 41.3 & 38.8 & 36.2 & $<75$ \\
$\mathrm{pH}$ & 8.2 & 7.9 & 8.3 & 7.6 & $\mathrm{ni}$ \\
$\mathrm{EC}\left(\mathrm{mS} \mathrm{cm}^{-1}\right)$ & 1.7 & 1.4 & 1.4 & 1.5 & $<1.5$ \\
$\mathrm{C} / \mathrm{N}$ & 14.0 & 13.9 & 14.8 & 12.2 & $\mathrm{ni}$ \\
$\mathrm{Ca}(\%)$ & 13.4 & 15.5 & 24.4 & 19.4 & $\mathrm{ni}$ \\
$\mathrm{Cd}\left(\mathrm{mg} \mathrm{kg}^{-1}\right)$ & $<0.25$ & $<0.25$ & $<0.25$ & $<0.25$ & $<1$ \\
$\mathrm{Cr}\left(\mathrm{mg} \mathrm{kg}^{-1}\right)$ & 53.1 & 44.5 & 31.0 & 27.5 & $<100$ \\
$\mathrm{~Pb}\left(\mathrm{mg} \mathrm{kg}^{-1}\right)$ & 9.75 & 9.38 & 7.78 & 10.3 & $<100$ \\
$\mathrm{Cu}\left(\mathrm{mg} \mathrm{kg}^{-1}\right)$ & 27.0 & 25.1 & 17.3 & 22.3 & $<100$ \\
$\mathrm{Ni}\left(\mathrm{mg} \mathrm{kg}^{-1}\right)$ & 19.8 & 21.0 & 11.8 & 10.4 & $<50$ \\
$\mathrm{Zn}\left(\mathrm{mg} \mathrm{kg}^{-1}\right)$ & 93.8 & 88.9 & 59.4 & 79.8 & $<300$ \\
\hline
\end{tabular}

EC, electrical conductivity; $\mathrm{C} 1-\mathrm{C} 4$, finished composts from piles 1 to 4 ; ni, value not indicated

a Criteria for the award of the European Community Ecolabel to soil improvers the lowest temperature recorded during compost process monitoring.

The results obtained for spores of sulphite-reducing clostridia (SSRC) in the matured composts, Fig. 3a, are relatively high, with the lowest value found for pile 1 . The quantification of SSRC is an important parameter, since clostridia are spore-forming bacteria that can resist to the high temperatures developed in the piles during the composting process [25]. Absence of Clostridium perfringens per gram of compost was suggested as an end-product requirement in the second draft of the European Commission working document on biological treatment of biowaste (2001). The results obtained in our work raise the suspicion that the time-temperature relationship was not enough to destroy the spores. Concerning the total MB level quantified in the starting raw materials, Fig. 3b, it is roughly $8.9 \log \mathrm{CFU} \mathrm{g}^{-1}$ and in the finished composts bacterial counts decreased to levels around 7.7-8.0 $\log \mathrm{CFU} \mathrm{g}{ }^{-1}$. These values were expected, because mesophilic microorganisms are still present in the maturation phase, despite the low microbial activities [26].

From the results presented it can be concluded that no significant differences were observed in the sanitation achieved in the end products with different levels of eggshell waste. It should also be noted that the degree of sanitation of the composts produced in this work may not be exclusively dependent on the temperature profile achieved during composting, but also on the recontamination phenomena associated with the use of the mechanical equipment to mix and aerate the piles. In fact, some authors $[25,26]$ have referred the recontamination or "redistribution" of faecal coliforms during the turnings of the windrows. Indeed, our experiments were performed in a local farm where the mechanical equipment was also used to mix and aerate other windrows involving animal manures and thus the recolonization of the composts may have occurred.

\section{Phytotoxiticity and Stability}

Germination index (GI) is a commonly used parameter to assess the phytotoxicity of composts because this is a problem associated with immature soil improvers that may contain inhibitory substances (e.g. ammonia, acetic acid, etc.) for seed germination and normal root development [24]. In our work, bioassays involving seed germination and growth were performed in liquid extract. In the literature, several types of seeds have been used to assess phytotoxicity and germination indices, since they are highly dependent on the type of seed employed [27]. Hence, some preliminary tests were conducted using finished compost from pile 1 (C1) to find the most sensitive among the seeds of garden cress, lettuce and tomato. The 


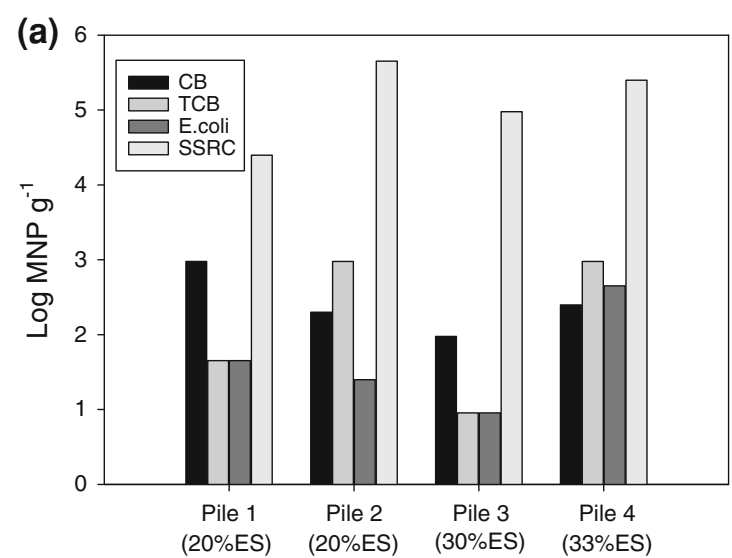

Fig. 3 Microbiological results for composts. a Total coliform bacteria (CB), thermotolerant coliform bacteria (TCB), Escherichia coli (E. Coli), Spores of sulphite-reducing clostridia (SSRC). b Total

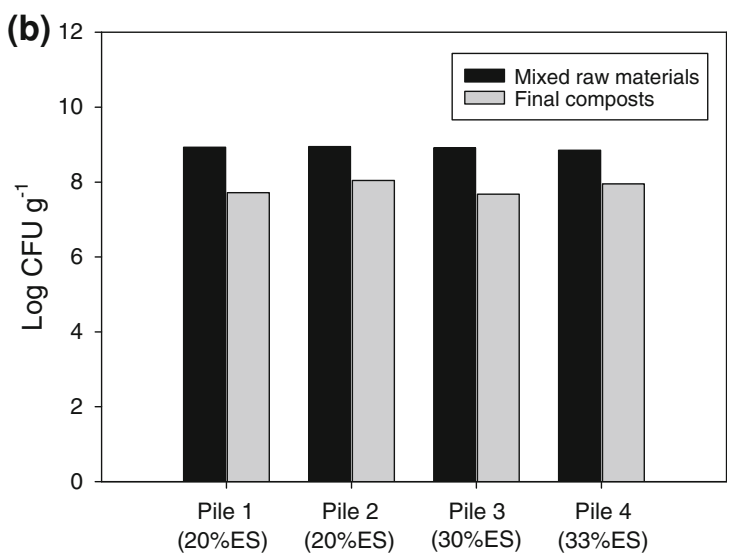

mesophilic aerobic bacteria (MB) at the beginning of composting process (mixed raw materials) and in composts produced
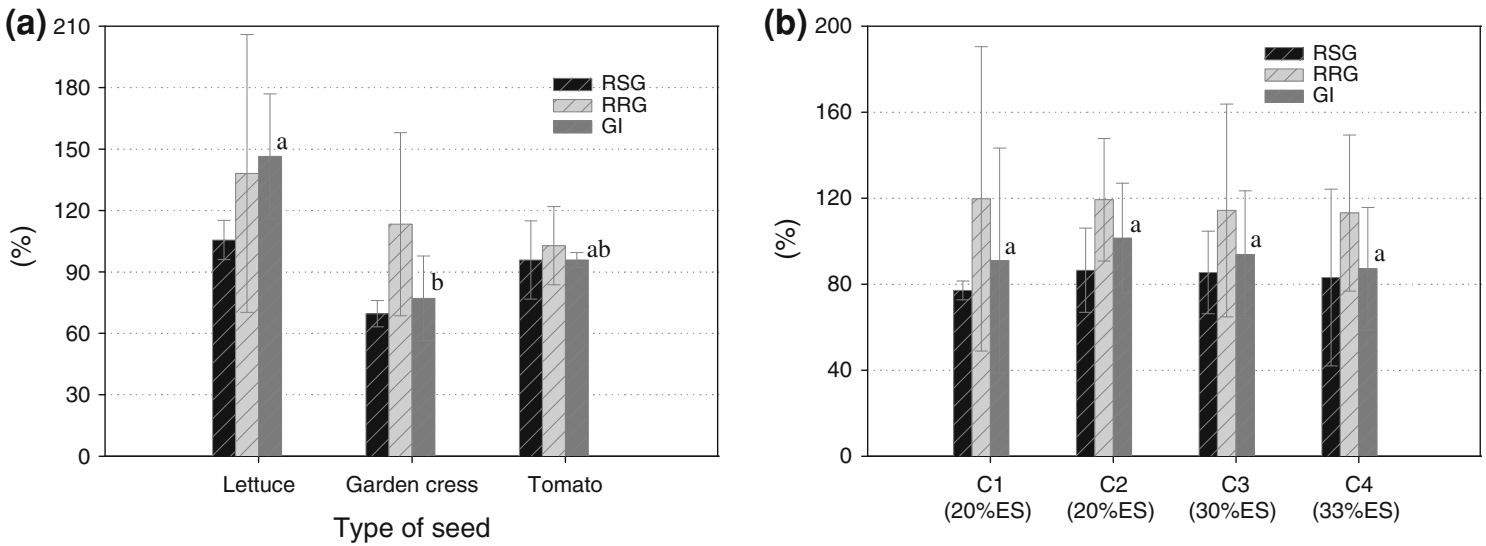

Fig. 4 Germination essays results (vertical lines represent SD). a For different types of seeds, using C1 $(\mathrm{n}=3$ ). b For different compost produced, using garden cress seeds $(\mathrm{n}=5)$. Different letters $(a$ and $b)$ indicate statistically significant differences in GI values

Table 5 Results for stability assessment of composts

\begin{tabular}{lll}
\hline Compost & $\begin{array}{l}\text { Maximum temperature } \\
\left({ }^{\circ} \mathrm{C}\right)\end{array}$ & $\begin{array}{l}\text { SOUR } \\
\left(\mathrm{mg} \mathrm{O}_{2} \mathrm{~g}^{-1} \mathrm{VS} \mathrm{h}^{-1}\right)\end{array}$ \\
\hline $\mathrm{C} 1$ & 29 & 0.29 \\
$\mathrm{C} 2$ & 28 & 0.24 \\
$\mathrm{C} 3$ & 29 & 0.19 \\
$\mathrm{C} 4$ & 28 & 0.36 \\
\hline
\end{tabular}

C1-C4, finished composts from piles 1 to 4 ; SOUR, specific oxygen uptake rate

results obtained are shown in Fig. 4a and the analysis conducted to the GI data revealed that garden cress and lettuce seeds are statistically different $(p<0.05)$. Therefore, it can be concluded that garden cress revealed a higher sensitivity to phytotoxic substances, since GI were the lowest of the three types of seeds tested. That sensitivity is due to the low relative seed germination (RSG) revealed by garden cress seeds when incubated in liquid compost extract. In Fig. 4b the parameters RRG, RSG and GI are indicated for all finished composts produced in our work, using only garden cress seeds.

Regardless of the compost composition, RRG was always superior to $100 \%$, meaning that the root length of the seeds is favoured by the substances extracted from the composts. Germination index (GI) observed are in the range of $87-101 \%$, and thus all of them are superior to $60 \%$. Therefore, it can be concluded that all composts are mature, without phytotoxic substances able to inhibit the germination [27]. It is important to note that the statistical analysis showed that there are no significant differences between GI values observed in composts $\mathrm{C} 1-\mathrm{C} 4(p<0.05)$. Thus, even if the starting mixture contains about $30 \%$ of ES, no negative influence is observed in GI parameter. Lower GI (from 32.5 to $50 \%$ ) were obtained by [13] in composts produced with eggshell waste and breeder and pullet litter, which 
points out that the phytotoxic characteristics of the composts produced with eggshell waste could only be attributed to the properties of the animal manure used in the windrows composition.

The stability refers to the rate or degree of organic matter decomposition expressed as a function of microbial activity and may be evaluated by means of respirometric measurements [27]. In our study, the self heating test using Dewar flasks and respirometric essays were performed to evaluate the stability degree of the composts produced. The self heating tests were carried out after 60 days from the beginning of the process. The ambient temperature recorded over 10 days was between 26 and $27^{\circ} \mathrm{C}$ and the maximum temperature inside the flasks was in the range of $28-29{ }^{\circ} \mathrm{C}$, Table 5 .

Thus, as the maximum temperature rise during the test period was lower than $10{ }^{\circ} \mathrm{C}$, all composts can be classified as very stable (Class V). The respirometric essays were performed after 120 days from the beginning, and according to data reported in Table 5, the highest SOUR were well below $1 \mathrm{mg} \mathrm{O}_{2} \mathrm{~g}^{-1} \mathrm{VS} \mathrm{h}^{-1}$ (limit for considering composts as stable [16]). Both tests clearly showed that all composts attained a high level of stability, and thus they can be used as soil improvers.

\section{Conclusions}

The feasibility of recycling through windrow composting large amounts of eggshell waste (animal by-product-ABP) combined with horse manure, chicken manure and grass clipping was investigated. The experimental results obtained indicate that regardless the formulation tested and in spite of the low $\mathrm{C}: \mathrm{N}$ ratio at the beginning of the process, thermophilic phase was observed in all windrows. The quality evaluation of the final composts showed that adequate physical and chemical properties were obtained with the materials tested and no phytotoxic characteristics were exhibited, even when more than $30 \%$ (w/ w) of eggshell waste was used. In fact, the assessment of maturity and stability of the final composts showed that windrows composting produced stable and mature composts, with good properties for agronomic applications. Although sanitation of the composts produced was not guaranteed, probably due to recontamination phenomena during windrow turning and short exposition to thermophilic temperatures, the microbiological assessment revealed that the composts may be used for agricultural applications in what concerns E. coli. In summary, this study showed that although the inorganic nature of eggshell waste, its valorization through composting processes is possible for producing a high Ca-rich soil improver.

Acknowledgments The CERNAS is supported by National Funds through FCT-Foundation for Science and Technology under the project "PEst-OE/AGR/UI0681/2011".

\section{References}

1. Consulting, A.C.: Study on the socio-economic implications of the various systems to keep laying hens-final report for The European Commission (2004)

2. Park, H.J., Jeong, S.W., Yang, J.K., Kim, B.G., Lee, S.M.: Removal of heavy metals using waste eggshell. J. Environ. Sci. 19, 1436-1441 (2007)

3. Mezenner, N.Y., Bensmaili, A.: Kinetics and thermodynamic study of phosphate adsorption on iron hydroxide-eggshell waste. Chem. Eng. J. 147, 87-96 (2009)

4. Tsai, W.-T., Hsien, K.-J., Hsu, H.-C., Lin, C.-M., Lin, K.-Y., Chiu, C.-H.: Utilization of ground eggshell waste as an adsorbent for the removal of dyes from aqueous solution. Bioresour. Technol. 99, 1623-1629 (2008)

5. Jones, D., Gittins, J.: Utilisation of Egg shell Waste from UK Egg Processing and Hatchery Establishments. ADAS Consulting Ltd, London (2002)

6. Larney, F.J., Yanke, L.J., Miller, J.J., McAllister, T.A.: Fate of coliform bacteria in composted beef cattle feedlot manure. J. Environ. Qual. 32, 1508-1515 (2003)

7. Chroni, C., Kyriacou, A., Manios, T., Lasaridi, K.-E.: Investigation of the microbial community structure and activity as indicators of compost stability and composting process evolution. Bioresour. Technol. 100, 3745-3750 (2009)

8. Farrell, M., Jones, D.L.: Critical evaluation of municipal solid waste composting and potential compost markets. Bioresour. Technol. 100, 4301-4310 (2009)

9. Kumar, K.N., Goel, S.: Characterization of municipal solid waste (MSW) and a proposed management plan for Kharagpur, West Bengal, India. Resour. Conserv. Recycl. 53, 166-174 (2009)

10. Sánchez-Arias, V., Fernández, F.J., Villaseñor, J., Rodríguez, L.: Enhancing the co-composting of olive mill wastes and sewage sludge by the addition of an industrial waste. Bioresour. Technol. 99, 6346-6353 (2008)

11. Sellami, F., Jarboui, R., Hachicha, S., Medhioub, K., Ammar, E.: Co-composting of oil exhausted olive-cake, poultry manure and industrial residues of agro-food activity for soil amendment. Bioresour. Technol. 99, 1177-1188 (2008)

12. Stadelman, W.J.: Eggs and egg products. In: Francis, F.J. (ed.) Encyclopedia of Food Science and Technology, 2nd edn. Wiley, New York (2000)

13. Kemper, N.P., Goodwin Jr, H.L.: Feasibility and production costs of composting breeder and pullet litter with eggshell waste. J. Appl. Poult. Res. 18, 172-184 (2009)

14. FCQAO: Methods book for the analysis of compost. KompostInformation Nr. 230. Budesgutegemeinschaft Kompost e.V. (1994)

15. Alburquerque, J.A., Gonzálvez, J., García, D., Cegarra, J.: Measuring detoxification and maturity in compost made from "alperujo", the solid by-product of extracting olive oil by the twophase centrifugation system. Chemosphere 64, 470-477 (2006)

16. Lasaridi, K.E., Stentiford, E.I.: A simple respirometric technique for assessing compost stability. Water Res. 32, 3717-3723 (1998)

17. Huang, G.F., Wong, J.W.C., Wu, Q.T., Nagar, B.B.: Effect of $\mathrm{C} / \mathrm{N}$ on composting of pig manure with sawdust. Waste Manage. (Oxford) 24, 805-813 (2004)

18. Zhu, N.: Effect of low initial $\mathrm{C} / \mathrm{N}$ ratio on aerobic composting of swine manure with rice straw. Bioresour. Technol. 98, 9-13 (2007)

19. Liang, C., Das, K.C., McClendon, R.W.: The influence of temperature and moisture contents regimes on the aerobic microbial activity of a biosolids composting blend. Bioresour. Technol. 86, 131-137 (2003) 
20. Bustamante, M.A., Paredes, C., Marhuenda-Ege, F.C., PérezEspinosa, A., Bernal, M.P., Moral, R.: Co-composting of distillery wastes with animal manures: carbon and nitrogen transformations in the evaluation of compost stability. Chemosphere 72, 551-557 (2008)

21. Li, X., Zhang, R., Pang, Y.: Characteristics of dairy manure composting with rice straw. Bioresour. Technol. 99, 359-367 (2008)

22. Zhu, N., Deng, C., Xiong, Y., Qian, H.: Performance characteristics of three aeration systems in the swine manure composting. Bioresour. Technol. 95, 319-326 (2004)

23. Yañez, R., Alonso, J.L., Díaz, M.J.: Influence of bulking agent on sewage sludge composting process. Bioresour. Technol. 100, 5827-5833 (2009)
24. Ko, H.J., Kim, K.Y., Kim, H.T., Kim, C.N., Umeda, M.: Evaluation of maturity parameters and heavy metal contents in composts made from animal manure. Waste Manage. (Oxford) 28, 813-820 (2008)

25. Bustamante, M.A., Moral, R., Paredes, C., Vargas-García, M.C., Suárez-Estrella, F., Moreno, J.: Evolution of the pathogen content during co-composting of winery and distillery wastes. Bioresour. Technol. 99, 7299-7306 (2008)

26. Hassen, A., Belguith, K., Jedidi, N., Cherif, A., Cherif, M., Boudabous, A.: Microbial characterization during composting of municipal solid waste. Bioresour. Technol. 80, 217-225 (2001)

27. Komilis, D.P., Tziouvaras, I.S.: A statistical analysis to assess the maturity and stability of six composts. Waste Manage. (Oxford) 29, 1504-1513 (2009) 